\title{
RUMOS DA DEMOCRATIZAÇÃO BRASILEIRA: A CONSOLIDAÇÃO DE UM MODELO MAJORITÁRIO DE DEMOCRACIA?
}

\author{
Luzia Helena Herrmann de Oliveira \\ Universidade Estadual de Londrina
}

\begin{abstract}
RESUMO
O objetivo do artigo é analisar as questões teóricas da consolidação democrática no Brasil, tendo em vista que o tema é controverso dentro da ciência política. A tese desenvolvida é que o modelo poliárquico de Dahl, costumeiramente apresentado como o referencial das democracias estáveis, não se adapta à análise dos processos de democratização em países como o Brasil, de passado autoritário. Propõe-se, assim, um estudo comparativo com os países do sul da Europa, hoje considerados democracias consolidadas, observando-se em que medida a relação entre partidos e governos no Brasil tende à consolidação de um modelo "majoritário" de democracia.
\end{abstract}

Palavras-chave: consolidação democrática; legitimidade política; partidos e governos.

\section{INTRODUÇÃO}

A nova ordem constitucional democrática no Brasil já completou doze anos, mas persistem dúvidas sobre a capacidade de o país consolidar sua democracia. A questão colocada é em que medida o Brasil caminha (ou não) para o que se convencionou chamar de consolidação democrática, ou seja, para a finalização de um processo de democratização que, embora não-linear, apresenta uma seqüência reconhecível. Em um primeiro momento, tem-se a transição, quando ocorre a mudança do regime, ainda mantendo fortes elementos do passado; em seguida, vem a instalação ou instauração, em que são implantadas as estruturas político-institucionais democráticas e são formalizadas novas regras de procedimento político; a permanência ou manutenção é a terceira etapa, quando as regras vão sendo sedimentadas

\footnotetext{
1 Este trabalho é resultado do estágio pós-doutoral que desenvolvi na Faculdade de Ciência Política Cesare Alfiere, da Universidade de Florença, entre setembro de 1998 e janeiro de 1999. Agradeço ao Professor Leonardo Morlino, que me proporcionou esta oportunidade valiosa, bem como aos Professores Jean Blondel, Maurizio Cotta e Luca Verzichelli, da Universidade de Siena, pelo relacionamento amigável e pelos subsídios teóricos adquiridos durante esses meses de convivência. Agradeço também ao CNPq pelo apoio, e à Marcolina Tomazini de Carvalho pela colaboração na pesquisa dos dados do PRODASEN.
}

em toda a sociedade; finalmente, pode-se chegar à consolidação, momento em que o sistema adquire sustentação, continuidade e legitimidade ${ }^{2}$.

Na conceituação de Linz e Stepan (1999), a consolidação propriamente dita é um estágio final, em que cinco campos em interação aparecem de forma plenamente visível: uma sociedade civil livre e ativa, com cidadãos e grupos que podem se expressar e se associar para defender suas opiniões e seus interesses; uma sociedade política relativamente autônoma e valorizada, na qual os partidos, as lideranças e as instituições democráticas são canais de intermediação entre a sociedade civil e o Estado; um Estado de Direito respeitado e valorizado tanto pela sociedade civil quanto pela sociedade política e pelo próprio Estado; uma burocracia estatal subordinada ao governo, capaz de prestar os serviços básicos à população; e, finalmente, uma sociedade econômica institucionalizada, que seria, na visão dos autores, "um conjunto de normas, instituições e regulamentações, construídas e acordadas de forma sócio-política" (LINZ \& STEPAN, 1999, p. 30) e que têm por função mediar as relações entre o Estado e o mercado.

\footnotetext{
2 O conceito de consolidação é especialmente tomado de Morlino (1998). A definição de Liz e Stepan (1999), embora mais enxuta, é essencialmente a mesma; ver também Di Palma (1990).
} 
É de se notar que a idéia de democracia consolidada não se distingue da institucionalização de Huntington (1975), pois é possível entenderse que nas democracias consolidadas, tal como nas democracias institucionalizadas, as normas e as instituições políticas encontram-se plenamente rotinizadas e incorporadas ao cotidiano dos cidadãos. Contudo, o conceito de consolidação não se reduz ao conceito de institucionalização, pois se refere a um processo que não obedece a um período seqüencial de estabilização e habituação (em alguns casos pode demorar décadas ou nem mesmo se concretizar) e, devido à incerteza que lhe é inerente, pode atravessar momentos de crises, rupturas e retrocessos, capazes de colocar em risco o desfecho desejado.

Como lembra Giuseppe di Palma (1990), o conceito de consolidação democrática diz respeito à consolidação de instituições democráticas e isso envolve uma malha de relações entre sociedade civil e Estado que interagem para a construção do novo modelo. Em cada momento do processo é importante observar-se não apenas as instituições criadas pelo novo regime, mas sobretudo a qualidade das alianças e das coalizões estabelecidas, verificando-se em que medida as escolhas estratégicas dos atores políticos contribuem positiva ou negativamente para a consolidação. Portanto, diferentemente de institucionalização, que é mais passiva, a consolidação é dinâmica e prospectiva, dependendo diretamente da ação dos atores em disputa.

O processo de democratização no Brasil inserese no movimento denominado terceira onda (HUNTINGTON, 1991), que se iniciou em 1974 com o fim da ditadura salazarista, em Portugal, e estendeu-se aos países da América Latina, Ásia e Europa. Essas novas democracias têm enfrentado dificuldades comuns que Huntington denomina problemas de transição, problemas contextuais e problemas sistêmicos.

Durante a transição surgem várias questões como, por exemplo, qual deve ser o procedimento mais correto das forças democráticas diante dos grupos políticos que apoiaram o regime autoritário e desrespeitaram os direitos humanos, matando e torturando civis que se opuseram à ditadura. $\mathrm{O}$ melhor seria negociar, ou romper e vingar-se? Outro dilema é o que fazer para reduzir o envolvimento das Forças Armadas na direção política do novo sistema. Um governo que se pretende democrático e soberano não pode aceitar imposições de forças políticas exteriores ao poder legitimamente constituído. Mas é sabido que em muitas dessas novas democracias os grupos políticos do regime anterior permaneceram no poder e os militares mantiveram uma profunda interferência na construção do novo regime.

Por problemas contextuais, Huntington compreende os chamados problemas endêmicos, constitutivos das sociedades em questão. Referese a acontecimentos específicos de cada realidade histórica, tais como a presença de grupos rebeldes, insurrectos que não aceitam a ordem jurídica democrática; a extrema pobreza que atinge um grande grupo de países; o profundo grau de desigualdade sócio-econômica a que outra parcela de países encontra-se submetida; a persistência de crises econômicas, como inflação, baixo índice de crescimento e desequilíbrios na balança de pagamentos.

Problemas sistêmicos encontram-se relacionados aos dois itens anteriores, mas aparecem de maneira mais visível no sistema político. Tornamse visíveis, seja pelo baixo grau de legitimidade democrática ou eficácia decisória dos governos, seja pela vulnerabilidade do sistema à demagogia política e à predominância dos interesses privados na vida pública.

No Brasil, as dificuldades políticas enfrentadas nas últimas décadas levaram os analistas a convergirem para a constatação de que, nesse país, a construção da democracia não tem sido tarefa fácil, persistindo tanto problemas do período da transição, quanto os endêmicos e os sistêmicos. A incerteza tem prevalecido nessas análises e a dificuldade teórica torna-se evidente porque a maior parte desses estudos toma como parâmetro as poliarquias de Dahl (1997), modelo fundamentado na história de países que não passaram pelas experiências dessas novas democracias. Embora relevantes, essas análises são prejudicadas pela dificuldade em comparar realidades históricas muito diversas. Um segundo problema é que embora a literatura disponível sobre a democratização brasileira seja bastante ampla, prevalece um grande desacordo, com interpretações e diagnósticos profundamente díspares.

A meu ver, para compreender os rumos da democratização brasileira seria mais útil o desenvolvimento de um estudo comparativo que reunisse democracias novas e, dentre essas, mais 
especificamente aquelas que conseguiram completar o ciclo da democratização, apresentandose hoje como democracias consolidadas. Refirome aos países do sul da Europa (Portugal, Espanha, Grécia e Itália incluída), os quais já vêm merecendo um grande número de análises dentro da política comparada. São estudos que têm procurado verificar em que medida tais países podem ser considerados casos paradigmáticos dos processos de consolidação democrática em curso no mundo atual ${ }^{3}$.

Como veremos a seguir, a partir dessa abordagem comparativa será possível dar um novo enfoque ao processo político brasileiro, observando aspectos que não têm merecido a atenção dos analistas. Uma análise abrangente dos vários processos de consolidação poderá acrescentar algo de importante ao debate sobre democracia que ora se desenvolve no Brasil. Antes, porém, é conveniente mostrar os pontos centrais desse debate.

\section{VISÕES SOBRE O PROCESSO DE CON- SOLIDAÇÃO DA DEMOCRACIA BRA- SILEIRA}

Em artigo recentemente publicado, Vicente Palermo (2000a) afirma que, embora as análises sobre o processo de democratização no Brasil tenham, em sua maioria, preferido observar a relação entre sistema de governo presidencialista e sistema partidário (considerado bastante fragmentado), as conclusões desses estudos têm apresentado profundas divergências. Realmente, a literatura produzida durante os últimos quinze anos sobre a democratização brasileira tende a dividir-se em tendências explicativas, cujas diferenças trazem embutidas visões distintas sobre a realidade histórica do país.

Uma primeira postura é aquela que procura enfatizar o caráter conservador da nova democracia brasileira, mostrando o quanto a transição manteve os aspectos autoritários vigentes no período anterior e o quanto esses aspectos continuaram influenciando, no sentido de cercear e limitar o alcance da democratização.

Um texto seminal desta primeira visão foi publicado em 1986, por Share e Mainwaring (1986),

\footnotetext{
3 Vários autores trabalham com essa hipótese. Ver, especialmente, Gunther et alii (1995).
}

no qual os autores apresentavam as semelhanças observadas entre a transição que se desenvolvia no Brasil e a transição espanhola, concluída alguns anos antes. Em ambos os casos, o governo autoritário teria mantido a transição sob seu controle e permanecido como força eleitoral relevante no momento seguinte à transição. Tais características são fundamentalmente importantes na explicação sobre esse tipo de transição pela transação, em que, implícita ou explicitamente, governo autoritário e oposições democráticas teriam estabelecido acordos, visando à abertura de novos espaços políticos para a oposição (em virtude principalmente da volta do mercado eleitoral e partidário) e a permanência dos antigos grupos do poder no cenário político. Para Share e Mainwaring, essa permanência interferiu decisivamente no processo de construção das regras institucionais do novo regime, contribuindo para que as mudanças institucionais e estruturais fossem bastante tímidas e conservadoras, determinando um caráter mais de continuidade que de ruptura.

Com a instauração do jogo constitucional democrático, uma expressiva parcela dos cientistas políticos procurou aprofundar essa interpretação, abordando aspectos da cultura política do país e da organização institucional do Estado que tenderiam a reforçar o sentimento de incerteza quanto à possibilidade de democratização. Essas análises apontavam as dificuldades políticas, relacionandoas ao modelo de transição adotado, ao modelo negociado, que manteve no cenário político os grupos que foram leais ao governo autoritário. Dentre esses grupos, destacavam-se os militares - que se mantiveram influentes, impondo uma série de restrições à nova ordem constitucional - e os grupos políticos tradicionais - que permaneceram no poder graças aos acordos firmados com a oposição.

Segundo tal raciocínio (O'DONNELL \& SCHMITTER, 1986; WEFFORT, 1992; HAGOPIAN, 1992), a oposição democrática foi cooptada no Brasil pela idéia da transição negociada e este processo garantiu a permanência na política brasileira de seus antigos vícios, ou seja: a prática desenfreada do clientelismo político, a fragilidade e a falta de opções programático-ideológicas dos partidos, e o comprometimento das instituições democráticas com o poder privado. Assim, o modo negociado da transição teria marcado profundamente o nascimento da nova democracia brasileira e, conseqüentemente, determinando em grande me- 
dida os momentos políticos posteriores. Daí a grande distância que o atual sistema mantém das modernas poliarquias ocidentais.

É claro que um sistema político com tais características, embora constitucionalmente democrático e com as instituições em pleno funcionamento, encontra-se muito distante da imagem de uma democracia consolidada. E essa constatação tem efetivamente sido feita por um número significativo de cientistas políticos, como Guillermo O’Donnell (1996), quando se refere ao sistema político brasileiro como democracia delegada ${ }^{4}$. Para O'Donnell, mesmo sob um regime político constitucional, o exercício da autoridade política no Brasil mantém os padrões tradicionais, preservando o extremo personalismo do presidente da República e a fraqueza das instituições democráticas, dos partidos e das organizações da sociedade civil.

Segundo esses analistas, a democracia que se desenvolve no Brasil seria uma democracia a meio caminho, que não se efetiva, não se consubstancia, podendo ser duradoura ou mesmo permanente, mas mantendo-se meramente formal e conservando os grupos privilegiados de sempre. Vale citar Eli Diniz (1997) quando afirma que a fragilidade do poder Legislativo frente ao Executivo é tradicional na política brasileira, visto que o país vem sendo dominado há muitas décadas pelo autoritarismo das burocracias estatais. Por essa razão, a autora entende que a consolidação da democracia brasileira depende de uma profunda transformação que envolva não apenas o Estado, mas sobretudo as relações entre Estado e sociedade.

Contrariando essa visão, contudo, outra parcela dos cientistas políticos desenvolve uma argumentação que nega a primeira teoria em, pelo menos, três pontos. Primeiro, na crença de que a transição democrática brasileira foi problemática pelo caráter negociado que evitou a ruptura com o momento anterior. Pelo contrário, estes autores acreditam que a maior dificuldade da transição brasileira foi não se ter estabelecido, de maneira pública, nenhum tipo de acordo político entre os grupos (democráticos e autoritários) que participaram da transição. Segundo, diferentemente dos analistas que costumam atribuir o mau funcionamento das instituições políticas brasileiras a fato-

\footnotetext{
4 Mais recentemente, o autor tem utilizado outros argumentos para defender a mesma idéia (O’DONNELL, 1999).
}

res macro-sociais, estes defendem a idéia de que a causa deve ser buscada no próprio processo de instauração da nova democracia e das escolhas políticas de seus atores. Terceiro, aparece entre tais autores uma enfática preocupação com a construção das regras do jogo democrático que, nessa ótica, passa a ser considerada um dos momentos cruciais do processo de consolidação.

Ludolfo Paramio (1989) encontra-se neste grupo à medida que procura desencorajar a formulação de algo semelhante a uma teoria das transições pactuadas, mostrando que os processos de democratização no Brasil e na Espanha apresentam significativas diferenças. Segundo Paramio, a atuação legalizada do partido oposicionista brasileiro (MDB) durante a ditadura militar contribuiu para diluir o posicionamento ideológico e político da oposição. Diferentemente, na Espanha, a clandestinidade compulsória durante a ditadura de Franco ajudou os oposicionistas a permanecerem com claras posturas programático-ideológicas que foram úteis no período da transição. Essa mesma análise aparece em Maria do Carmo Campello de Souza, quando argumenta que na transição brasileira prevaleceu um "vasto centro (partidário-parlamentar) - um espaço onde todos estão com todos e de que não se conhecem nem os limites nem a espinha dorsal" (SOUZA, 1988, p. 569). Segundo os dois autores, tal embaralhamento ideológico foi prejudicial à transição brasileira.

Para os adeptos dessa teoria, no Brasil o processo de transição foi muito prejudicado porque misturou a temática social e econômica à discussão sobre a regulamentação formal do novo sistema democrático. Com isso, relegou para um segundo plano a organização do sistema político, que seria fundamental para a instauração da democracia. Segundo Bolívar Lamounier, a transição democrática brasileira foi extremamente competitiva e desgastante para os dois lados (democratas e autoritários), criando um impasse prejudicial, porque os problemas sociais e políticos avolumaramse sem que um dos segmentos ou uma liderança legítima fosse capaz de tomar a direção do processo. Não houve, segundo ele, "um foro apropriado para a focalização das atenções em diagnósticos globais", prevalecendo temas pontuais e desarticulados, em lugar da construção de uma "engrenagem institucional mais ampla" (LAMOUNIER, 1996, p. 22).

Sob essa ótica, não há dúvida de que uma das 
maiores dificuldades para a consolidação democrática brasileira é a incapacidade de formularem-se regras político-institucionais duradouras. Dois aspectos são reiteradamente lembrados por esses analistas: de um lado, a importância do consenso democrático na formulação das leis fundamentais; de outro, a necessidade de fortalecer o sistema, para facilitar a tomada de decisões e, assim, permitir a eficácia dos governos (a governabilidade). Dessa maneira, o acordo político sobre a organização institucional é considerado de primordial importância, primeiro, porque contribuiria para dar legitimidade ao sistema e, segundo, porque as regras vigentes no Brasil têm sido consideradas profundamente inadequadas ao aprimoramento democrático do país.

Para eles, um dos pontos nodais da questão é que a permissividade da legislação partidária e o extremo consociativismo do sistema eleitoral no Brasil conflitam com o sistema presidencialista, dificultando a formação de maiorias parlamentares de apoio ao poder Executivo. Note-se, portanto, que em lugar da clássica noção de equilíbrio dos poderes, a opção aqui é por um sistema capaz de "desenvolver uma série de incentivos para a geração de maiorias coligadas" (LINZ \& STEPAN, 1999, p. 218). Implantação do sistema parlamentarista e reformas no sistema partidário-eleitoral teriam por objetivo harmonizar a relação entre os poderes, estruturando-os para que adquiram capacidade de enfrentar as questões-chave que têm impedido a consolidação democrática 5 .

Em última instância, a consolidação da democracia no Brasil dependeria da solução dos problemas de política substantiva: a busca por maior equilíbrio sócio-econômico, visto que hoje a desigualdade atinge um dos piores índices do planeta; o desenvolvimento de um legítimo Estado de Direito, que seja capaz de garantir, com imparcialidade, o respeito aos direitos de cidadania; a construção de uma eficiente burocracia estatal, dirigida para a promoção do desenvolvimento econômico

\footnotetext{
5 A bibliografia sobre a necessidade da reforma é muito ampla. Ver, sobre as dificuldades do sistema presidencialista combinado com o pluripartidarismo, Mainwaring (1993) e os artigos de Bolívar Lamounier, Juan Linz, Arend Lijphart e Arturo Valenzuela em Lamounier (1991). Sobre a desproporcionalidade do sistema eleitoral, ver Nicolau (1991). Uma análise do debate no Brasil encontra-se em Oliveira (1997).
}

e para o atendimento às demandas da sociedade 6 . Contudo, os adeptos dessa linha de análise acreditam que o trabalho de engenharia política, quando bem sucedido, pode facilitar a superação destes obstáculos.

Esta postura, entretanto, vem sendo criticada em uma série de estudos recentes. Polemizando com essa interpretação, análises direcionadas mais especificamente para o processo decisório do Estado têm frisado que, durante a última década, o poder Executivo no Brasil manteve grande autonomia, assumindo crescentemente atribuições legislativas e mantendo à sua disposição uma série de mecanismos institucionais e informais, capazes de constranger e disciplinar o Congresso Nacional.

O objetivo desses novos trabalhos é demonstrar que o poder Executivo detém o controle decisório no Brasil e que, portanto, o país não corre o risco da ingovernabilidade. Como salienta Vicente Palermo, os teóricos desta linha criticam as visões anteriores, afirmando que elas "não levam em conta todas as variáveis relevantes" (PALERMO, 2000a, p. 537). Vários autores têm abordado aspectos dessa questão.

Argelina Figueiredo e Fernando Limongi (1996; 1997 ; 1998) têm publicado uma série de trabalhos que esmiúçam o processo de tramitação dos projetos de lei, mostrando que alguns procedimentos usuais do processo decisório garantem o controle do poder Executivo sobre o Legislativo e evitam a dispersão e a pulverização dos votos parlamentares. Segundo eles, o sistema político inaugurado em 1988 garantiu ao poder Executivo prerrogativas legais que the conferem grande autonomia e capacidade de interferência sobre o poder Legislativo como, por exemplo, a concentração de poder no Colégio de Líderes e na Mesa Diretora dentro do Congresso Nacional. Essas prerrogativas legais garantem a entrada para a pauta legislativa apenas dos projetos que interessam às lideranças parlamentares que controlam o Legislativo e que estão afinadas com o poder Executivo.

A iniciativa legislativa de editar Medidas Provisórias é outra forma de intervenção que garante enorme autonomia ao poder Executivo, princi-

\footnotetext{
6 Estas questões são discutidas por Linz e Stepan (1999), quando se referem à ausência desses campos democráticos no Brasil. Também Bolívar Lamounier estabelece uma relação direta entre desconcentração de renda e consolidação da democracia brasileira (LAMOUNIER, 1995).
} 
palmente porque o Legislativo tem, muitas vezes, abdicado do direito de analisar a admissibilidade da lei, aceitando para discussão todos os projetos que o poder Executivo considera urgentes e relevantes. Além disso, o poder Legislativo permite a reedição das matérias não examinadas pelo Congresso no prazo legal de trinta dias. Com isso, sem passar pela apreciação do Congresso, algumas dezenas de Medidas Provisórias vêm sendo sucessivamente reeditadas durante os últimos dez anos (FIGUEIREDO \& LIMONGI, 1997).

$\mathrm{O}$ alto índice de fragmentação partidária do sistema político brasileiro também não deve ser considerado um empecilho ao desenvolvimento democrático. Em Multipartidarismo e democracia, Jairo Nicolau afirma que a fragmentação partidária é um elemento constitutivo da política brasileira (principalmente a partir da década de 90), mas em nenhum momento "a fragmentação apareceu como um problema” (NICOLAU, 1996, p. 105). Segundo ele, sistemas multipartidários estimulam a formação de governos de coalizão, e isso vem efetivamente ocorrendo no Brasil.

Rachel Meneguello reafirma essa postura quando analisa a relação entre partidos e governos no Brasil democrático. Para isso, apóia-se no levantamento da formação ministerial de todos os governos federais desde 1985, concluindo que "os partidos exercem papel central na organização e funcionamento do poder Executivo" (MENGUELLO, 1998, p. 165). Segundo ela, a autonomia do presidente da República é limitada pela interferência dos partidos no processo decisório e estes, por sua vez, têm interesse nessa proximidade para desenvolvimento de suas políticas. Dessa forma, cria-se um círculo vicioso que favorece a coalizão e a governabilidade.

Como se sabe, governo de coalizão é uma característica dos modelos consociativos de democracia, mas para grande parte desses analistas o alto grau de controle do poder Executivo e a eficácia decisória do governo estariam demonstrando que se desenvolve no país um modelo com características de "majoritarismo exacerbado" ou "lógica majoritária"7. O ponto fundamental é que o Presidente da República, aliado às lideranças partidárias que dão sustentação política ao governo, conse-

\footnotetext{
7 O primeiro termo é de Figueiredo et alii (2000, p. 50) e o segundo de Cláudio Gonçalves Couto (apud PALERMO, 2000a, p. 535).
}

guiria determinar a agenda legislativa, controlando todo o processo político.

No entanto, mesmo dentro dessa perspectiva teórica que enfatiza a governabilidade, uma leitura atenta leva-nos a concluir que a consolidação da democracia não foi atingida. Mesmo esses autores têm constatado que a eficácia decisória acontece graças à utilização rotineira de mecanismos políticos de legitimidade duvidosa. Medidas Provisórias que não são apreciadas pelo Congresso Nacional (PESSANHA, 1999), a desorganização partidária 8 e a prática da política invisível ${ }^{9}$ são expedientes que podem funcionar no curto prazo, mas é difícil prever como serão recebidos pela sociedade no futuro próximo. Como alguns pesquisadores vêm percebendo, a dinâmica partidária observada na prática parlamentar mais recente indica que "o processo político brasileiro está marcado por uma incerteza muito maior do que os autores representativos do terceiro enfoque (concentração de poder/governabilidade) registram" (PALERMO, 2000a, p. 539).

Sendo esse raciocínio verdadeiro, observa-se que muitas questões sobre os rumos da democratização brasileira permanecem em aberto. $\mathrm{O}$ ponto de vista desenvolvido neste artigo é que a consolidação democrática envolve elementos que vão além da governabilidade, pois, independentemente dos problemas relativos à preservação do sistema político e da eficácia dos governos, há que se considerar a qualidade da democracia que vem sendo construída. Como será visto a seguir, uma comparação com os países do sul da Europa será útil para mostrar que determinadas questões aparecem como centrais nesse processo.

\footnotetext{
8 Como observa Jairo Nicolau (1996, p. 98), “A intensa troca de legenda [...] sem dúvida é um sinal da pouca institucionalização dos partidos brasileiros. Porém, é possível avaliar seus efeitos como funcionais para a operação do presidencialismo brasileiro, já que facilitam o processo de ampliação de sustentação parlamentar do Executivo".

9 Ao analisar a aprovação da Lei da Previdência Social, Figueiredo e Limongi (1998, p. 65) argumentam que "a implantação de reformas que visam cortar e limitar benefícios é condicionada por fortes resistências da parte de grupos de interesse e burocracias constituídas em torno dos programas existentes e pelo apoio popular a determinados programas. Portanto, a aceitação dessas políticas depende do uso de estratégias que permitam diminuir a visibilidade e a possibilidade de identificação dos responsáveis últimos pela aprovação das reformas”.
} 


\section{UM OLHAR COMPARADO COMO PRO- POSTA ANALÍTICA}

Em período relativamente curto, os países do sul da Europa (Espanha, Portugal, Grécia e Itália ${ }^{10}$ ) conseguiram completar o ciclo da democratização, constituindo-se nos casos mais bem-sucedidos de transição democrática ocorridos desde a década de $70^{11}$. Apresentando em comum a permanência do regime autoritário e um índice de desenvolvimento econômico inferior à média dos países europeus, o sul da Europa passou por uma profunda transformação durante as três últimas décadas, conseguindo institucionalizar a cultura democrática e avançar significativamente seus padrões sócioeconômicos. Analisando-se a trajetória de cada um desses países, é surpreendente observar a diversidade dos caminhos percorridos no que diz respeito a questões essenciais, como as que foram discutidas na segunda parte deste artigo. Se não, vejamos.

\section{III.1 OS PROCESSOS DE CONSOLIDAÇÃO: ESPANHA, PORTUGAL, GRÉCIA E ITÁ- LIA}

A Espanha é considerada o modelo por excelência da transição pactuada, no qual todas as forças relevantes (da extrema direita à extrema esquerda) contribuíram decisivamente para a instauração da nova democracia. A transição espanhola iniciou-se em 1975 quando, após a morte do General Franco, o próprio regime tomou consciência de que o autoritarismo havia se esgotado, embora a oposição não tivesse força para, sozinha, tomar o poder. Foi então que o rei Juan Carlo tomou a direção do processo, incumbindo-se de organizar o desmonte da estrutura institucional franquista e construir a nova democracia.

Em 1976, a Lei para a Reforma Política, aprovada em referendo popular, promoveu uma

10 Em rigor, a Itália não deveria ser incluída na análise, porque sua transição para a democracia ocorreu na década de 40, com a derrota do regime fascista durante a II Guerra. Mas, em virtude das similaridades históricas entre esses países, também o caso italiano tem sido estudado.

11 Dentre os países que passaram por transições democráticas durante as últimas décadas, o Uruguai, a Hungria e a República Checa têm sido igualmente incluídos entre as democracias consolidadas; cf. Linz et alii (1995). profunda mudança na composição do Legislativo, abrindo a possibilidade de uma ampla participação partidária. Em junho de 1977, foram realizadas as eleições do Parlamento incumbido de elaborar a nova Constituição. Em 1978, a Constituição foi aprovada por meio de referendo. Todas as reformas posteriores foram fruto de pactos envolvendo os partidos e lideranças vitoriosos nas eleições nacionais. Em 1981, uma frustrada tentativa de golpe militar recebeu inequívoca rejeição da opinião pública espanhola, bem como de todos os grupos políticos importantes. Em 1982, os socialistas venceram as eleições e indicaram o Primeiro-Ministro, Felipe Gonzáles. Há consenso entre os cientistas políticos de que, neste momento, a democracia espanhola já havia se consolidado.

O caso espanhol apresenta peculiaridades que têm sido apontadas como importantes para o sucesso de sua democratização. De um lado, a memória da Guerra Civil contribuiu para colocar sociedade e grupos políticos a favor da democracia e do Estado de Direito. Além disso, os segmentos militares não exerceram papel atuante no governo autoritário e a economia não apresentava problemas sérios que pudessem acirrar o conflito social. De outro, o nacionalismo das regiões basca e catalã, que poderiam limitar fortemente a legitimidade das mudanças, foi controlado com uma inteligente organização da agenda eleitoral, iniciada com eleições nacionais e terminada com um referendo em que se indagava a viabilidade da autonomia dessas regiões. Como argumentam Linz, Stepan e Gunther (1995), a correta elaboração da agenda foi importante para evitar problemas de estatalidade que poderiam colocar em risco a democratização ${ }^{12}$.

Em relação ao apoio da sociedade à democracia, pesquisas de opinião mostram que a Espanha apresentava um baixo percentual de segmentos sociais anti-democráticos, bem como de grupos e partidos anti-sistema. No entanto, a organização partidária - que sempre é observada com atenção pelos analistas, por ser considerada um canal de fundamental importância na vida democrática - apresentava uma atuação ambígua

\footnotetext{
12 Os autores comparam os problemas da Espanha com os conflitos étnicos da Iugoslávia e União Soviética, afirmando que estes foram agravados por uma escolha equivocada da agenda eleitoral (LINZ et alii, 1995).
} 
na Espanha. Embora as lideranças partidárias tenham sido fundamentais durante a transição e a instauração da democracia, verificava-se um grau muito baixo de identificação partidária com a sociedade. Também o relacionamento entre partidos e grupos de interesse não apresentava relações tão estreitas quanto em outros países da Europa. Pode-se observar também que as lideranças partidárias, especialmente as do Partido Socialista (PSOE), foram plenamente dominantes durante todo o período, exercendo um papel crucial na consolidação da democracia espanhola.

Dentre os países da chamada terceira onda, Portugal foi o que iniciou primeiro a transição para a democracia (em 1974) mas, diferentemente da Espanha, não desenvolveu nenhum tipo de pacto, pois o governo foi derrubado por jovens oficiais que se opunham à política colonialista de Portugal. O sucesso do golpe deveu-se, em grande parte, ao apoio maciço da sociedade portuguesa, que saiu às ruas empunhando cravos vermelhos e apoiando o fim do autoritarismo.

Com a tomada do poder pela junta militar, iniciou-se uma fase de profundas transformações: no campo da economia, prevaleceu o teor socializante, implantando-se a nacionalização dos bancos e a tomada de fábricas e propriedades rurais; no campo da política, os militares assumiram todos os postos de comando (legislativos, executivos e judiciários), adotando um rígido controle sobre a sociedade civil, com base na justificativa de que era necessário afastar os grupos leais ao regime anterior. Esses segmentos militares aproximaramse dos partidos revolucionários portugueses, dentre os quais o mais relevante era o Partido Comunista (PCP), de linha stalinista.

Durante esse tumultuado período que durou dois anos, não havia indícios de que a transição portuguesa caminharia para a consolidação democrática. Contudo, dois acontecimentos alteraram esse processo. Primeiro, as eleições para a Assembléia Constituinte, que estavam previstas no programa revolucionário do Movimento das Forças Armadas, e efetivamente foram realizadas em abril de 1975. Nessas eleições, os partidos democráticos obtiveram $72 \%$ dos votos, sinalizando claramente que a sociedade optava pela democracia. $\mathrm{O}$ segundo fato relevante aconteceu no interior das próprias Forças Armadas, quando o Coronel Ramalho Eanes, apoiado por um grupo de oficiais de alta patente e por forças civis de Portugal e do exterior, deu um contra-golpe dentro das Forças Armadas, impondo a retomada da ordem e da hierarquia militar.

Como é perceptível nesta sumária descrição da transição democrática portuguesa, as Forças Armadas exerciam amplo controle sobre a sociedade e sobre os partidos, afetando profundamente o processo de consolidação. O Conselho Revolucionário, composto por militares, impunha uma série de restrições às instituições e às forças políticas, atuando como uma reserva de domínio que se auto-proclamava um organismo de supervisão do Estado. Por sua interferência direta, a Constituição portuguesa de 1976 continha uma série de artigos que legalizavam a atuação do Conselho.

Analisando a trajetória política portuguesa durante essa fase, os pesquisadores tendem a concordar que um fator importante para a consolidação democrática foi o declínio eleitoral dos partidos anti-sistema. Isso fez com que os partidos democráticos gradativamente adquirissem força para realizar a reforma constitucional de 1982, que extinguiu o Conselho da Revolução e reorganizou o Estado em moldes plenamente democráticos. Observam, também, que a transição portuguesa demonstra uma faceta paradoxal, pois ao mesmo tempo em que a sociedade, majoritariamente, apoiava a democracia, o sistema partidário português estava entre os mais polarizados de todo o sul da Europa. Apenas a Grécia assemelhava-se a Portugal, no que se refere à relevância dos partidos anti-sistema atuando naquele período.

Numa primeira fase, o Partido Comunista foi preponderante, seja por suas relações com o Movimento das Forças Armadas, seja porque mantinha ligações estreitas com as organizações trabalhistas, incentivando a mobilização social revolucionária. Numa segunda fase, caracteristicamente parlamentar e eleitoral, o Partido Comunista perdeu relevância, sendo substituído pelo Partido Socialista (PSP), que era central e mais programático, e pelo Partido Social Democrata (PSD), que possuía uma vasta teia de ligações com as localidades, com os grupos organizados e com outras formas de representações da micropolítica. Também o conservador Centro Democrático Social (CDS) mantinha profundas ligações clientelistas e personalistas. A organização partidária foi fundamental para a consolidação da democracia portuguesa, principalmente por sua atuação no Parlamento durante a segunda fase do processo. 
A transição para a democracia na Grécia foi rápida (menos de um ano), porque o regime autoritário não conseguiu apoios significativos durante os sete anos em que esteve no poder (19671974). A base de sustentação do regime era muito estreita, havendo evidentes divisões no interior das Forças Armadas, assim como a franca oposição da monarquia e de grande parte dos políticos e da sociedade civil.

Em 1973, os protestos estudantis contra a ditadura receberam amplo apoio da sociedade, mas a derrota do governo autoritário só foi precipitada pela intervenção da Grécia no golpe político do Chipre, e pela posterior invasão do Chipre pela Turquia. A tibieza do governo grego diante da ameaça de guerra levou o Estado-Maior grego a isolar as Forças Armadas do governo, facilitando a deposição dos militares que controlavam o regime. Foi o próprio Estado que negociou o retorno do líder político conservador Constantine Karamanlis, entregando-lhe o poder com a garantia de que as Forças Armadas permaneceriam afastadas dos próximos governos que viriam a ser formados.

Karamanlis iniciou uma grande reforma. No curto período de 142 dias, o regime autoritário foi desmontado, extinguindo-se a monarquia através de um referendo, legalizando-se os partidos comunistas, abolindo-se leis discricionárias do regime militar e realizando-se eleições para a abertura do Parlamento. Os militares que haviam sido expurgados pela ditadura foram chamados de volta e os militares comprometidos com o regime foram presos, julgados e, muitos deles, condenados. Pode-se dizer, portanto, que a transição estava completada. O período de consolidação, no entanto, foi mais longo, em virtude dos desacordos partidários que se verificaram nos anos seguintes.

A nova Constituição, escrita pelos parlamentares eleitos, foi elaborada com a participação de todos os partidos relevantes e não sofreu interferências que denotassem reservas de domínio. No entanto, a legitimidade da Carta foi duramente contestada pelos partidos de oposição que, em razão das regras eleitorais, ficaram drasticamente sub-representados no Congresso Constituinte. A Nea Democratia (ND), partido conservador do primeiro-ministro Karamanlis, recebeu $54,4 \%$ dos votos, mas conquistou $73,3 \%$ das cadeiras parlamentares. Os partidos da oposição, o socialista
PASOK (Movimento Socialista Pan-Helênico) e os partidos comunistas, KKE (pró-Moscou) e KKI (euro-comunista), ficaram limitados a 6,7\% das cadeiras, o que reduziu significativamente sua influência na redação da Constituição (ALIVIZATOS, 1990).

Os partidos encontravam-se profundamente polarizados, não somente por suas divergências político-ideológicas, mas principalmente pela desconfiança recíproca, dificultando a democratização na Grécia. Contudo, alguns elementos parecem ter contribuído para a consolidação. Primeiramente, a atitude predominantemente democrática da sociedade: uma pesquisa desenvolvida por Leonardo Morlino e José Montero nos quatro países do sul da Europa mostrou que a população grega era a que demonstrava maior apego à democracia e guardava a pior lembrança dos tempos da ditadura ${ }^{13}$. Em segundo lugar, a transformação política dos partidos de esquerda que, gradativamente, foram-se incorporando ao jogo parlamentar. Nessa fase, cresceu a aceitação do PASOK junto à opinião pública e os partidos comunistas perderam apoio eleitoral, o que levou o conflito partidário a reduzir-se, fundamentalmente, a dois grandes partidos: o direitista ND e o esquerdista PASOK.

Durante os anos 80, estudos demonstram uma progressiva aproximação entre esses dois partidos, não apenas na forma de atuação política (o corporativismo de Estado, o localismo e o clientelismo político não têm sido exclusividade da direita), mas sobretudo nos acordos informais dentro do Parlamento. Há divergências, entre os analistas, sobre o momento em que a democracia grega poderia ser considerada consolidada. Para determinados autores, é possível afirmar que isso aconteceu já no final dos anos 70 , quando os partidos de esquerda passaram a demonstrar grande adaptabilidade ao jogo eleitoral. Para outros, a certeza da consolidação veio em 1981, quando o PASOK venceu as eleições, possibilitando a alternância do poder.

\footnotetext{
13 Afirmaram que "a democracia é sempre preferível": $87 \%$ dos gregos, $70 \%$ dos italianos, $70 \%$ dos espanhóis e $61 \%$ dos portugueses; que o passado autoritário foi "ruim": 59\% dos gregos, 37\% dos italianos, $28 \%$ dos espanhóis, 30\% dos portugueses; que "a democracia funciona bem": $35 \%$ dos gregos, 4\% dos italianos, $8 \%$ dos espanhóis, 5\% dos portugueses (MORLINO \& MONTERO, 1995, p. 236).
} 
O processo de consolidação da democracia na Itália diferencia-se em vários aspectos dos casos anteriormente apresentados. Na questão do tempo transcorrido, foi o que mais demorou para consolidar-se, pois, embora a transição tenha sido rápida, os conflitos partidários posteriores criaram um clima de instabilidade. Na questão da organização política da sociedade, observa-se também que a Itália se destaca. Em comparação entre os quatro países, Leonardo Morlino mostra que a Itália apresenta percentuais bastante superiores de identificação e filiação partidária ${ }^{14}$.

Nesse país, a democratização iniciou-se em 1943, após a derrota fascista. Com o fim do regime, monarquistas e políticos ligados ao antigo sistema procuraram controlar o processo de transição, mas a oposição (a chamada coalizão antifascista) foi unanimemente contra, conseguindo afastá-los do processo decisório.

A formação da Assembléia Constituinte representou um momento de grande consenso em torno da democracia e a instauração democrática foi igualmente bem-sucedida. Esse acontecimento pode ser considerado extraordinário, pois conflitos ideológicos no interior da Assembléia Constituinte tendiam a impedir o consenso, mas essas divergências foram paulatinamente contornadas. Por exemplo, relativamente ao sistema eleitoral, a direita ideológica preferia o sistema majoritário, os governistas procuravam impor fórmulas que favorecessem a maioria e a esquerda defendia o voto facultativo e um sistema bastante proporcional. Como explica Maurizio Cotta (1990), o conflito foi solucionado com a organização de um sistema que privilegiou o atendimento às demandas fragmentadas presentes no Parlamento. Se isso provocou, de um lado, um prejuízo à coerência e à homogeneidade da Constituição, de outro foi vantajoso, porque acomodou interesses contraditórios, garantindo a legitimidade do novo regime.

O período da consolidação da democracia italiana (entre 1947 e meados dos anos 70) foi igualmente de grande complexidade. Durante quase três décadas o sistema partidário manteve-se

14 Identificação partidária em 1989: 49\% em Portugal; 30\% na Espanha; 57\% na Grécia e 63\% na Itália. Quanto ao índice de filiação partidária, a Itália aparece em primeiro lugar, seguida da Grécia, Portugal e Espanha, nessa ordem (MORLINO, 1995). altamente polarizado, com os três maiores partidos apresentando profundas diferenças entre si: o maior partido era o PDC (Partido Democrata-Cristão), democrático, confessional, do tipo "pegatodos" e profundamente ligado aos interesses locais e privados; diferentemente, o PCI (Partido Comunista Italiano) mantinha uma retórica antisistema e caracterizava-se pela organização centralizada junto aos movimentos sociais; o PSI (Partido Socialista) procurava seguir os moldes organizacionais do PCI, mas, na realidade, era federalizado e dependente de lideranças locais. Foram esses três partidos (combinados a um número expressivo de outros menores) que compuseram o enredo da democratização italiana.

O PDC manteve-se no gabinete executivo por cerca de quatro décadas, graças às composições com o Partido Socialista e outros pequenos partidos, impedindo, assim, que o Partido Comunista conquistasse o poder. O PCI permaneceu durante todos esses anos com uma expressiva representatividade parlamentar, sem contudo atingir percentual suficiente para formar a maioria de governo. Como oposição, entretanto, os comunistas eram bastante fortes, preservando o caráter policêntrico do Parlamento italiano, conforme definição de Maurizio Cotta (1996).

Análises têm mostrado que o sistema político italiano, para o bem e para o mal, possibilitou a participação da oposição e dos interesses privados no jogo parlamentar, integrando-os ao sistema político $^{15}$. Em meados da década de 70, o Partido Comunista Italiano encontrava-se plenamente integrado ao jogo parlamentar. Nessa fase, uma reforma política ampliou os poderes das comissões parlamentares, aumentando a capacidade de interferência do PCI no poder. É nesse momento que os cientistas políticos tendem a considerar a democracia italiana consolidada.

Nos anos 90, uma profunda crise política abalou toda a Itália, envolvendo partidos e governo em escândalos de corrupção e outras denúncias criminais. Esses acontecimentos abalaram fortemente a sociedade italiana, provocando transformações políticas e mudanças no quadro partidário: os partidos tradicionais foram duramente golpeados e, à direita do espectro ideológico, surgiram

15 Ver, especialmente, Cotta (1990) e Morisi (1991). 
novos partidos, como a Forza Itália, a Lega Nord e o neo-fascista Alianza Nazionale.

Tais mudanças têm suscitado discussões importantes na Itália, sobre a necessidade de reformas políticas que fortaleçam o poder Executivo. Buscando compreender os motivos da crise, Maurizio Cotta (1996) analisa a vulnerabilidade de um sistema político que privilegiou, concomitantemente, os grandes embates ideológicos e o exercício cotidiano da micropolítica. Para ele, os problemas relativos à organização econômica, social e institucional do país - as chamadas mesopoliticas -, que são cruciais e que verdadeiramente interessam à sociedade mais ampla ${ }^{16}$, não mereceram a devida atenção dos governos democráticos italianos. Daí ter advindo a crise.

\section{UM MODELO MAJORITÁRIO DE DEMO- CRACIA?}

Muitas facetas dos processos descritos acima poderiam ser esmiuçadas em um exercício comparativo com o Brasil e, efetivamente, alguns desses aspectos já vêm sendo analisados, como acontece com as questões relativas à cultura política e ao sistema político-institucional. Entretanto, creio ser oportuno voltar aos temas que têm dominado o debate político brasileiro, conforme foi apresentado na segunda parte deste artigo.

\section{IV.1 RELAÇÃO ENTRE OS PODERES EXE- CUTIVO ELEGISLATIVO}

Um primeiro ponto a ser destacado diz respeito à relação entre os poderes Executivo e Legislativo. Certamente, um dos estudos mais profícuos sobre a relação entre esses poderes nos países do sul da Europa é de Lijphart et alii (1988), por demonstrarem que estas democracias não apresentam características específicas que as distingam das outras democracias ocidentais, podendo ser colocadas ao longo do contínuo democracias majoritárias-democracias consociativas ${ }^{17}$, ou seja, ao longo das formas de organização do Estado democrático que privilegiam ou o poder concentrado da maioria de governo, ou o poder equilibrado

16 Cotta apóia seu argumento na pesquisa de opinião organizada por Morlino e Montero, que mostra a insatisfação do povo italiano com a política do governo; esses dados estão reproduzidos na nota 13 .

17 O artigo é uma referência direta ao livro de Lijphart (1984). Os dados referentes à Itália encontram-se nesse livro. entre o maior número possível de partidos (inclusive da oposição).

Analisando esses aspectos, os autores concluem que apenas a Itália pode ser considerada caracteristicamente consociativa; Portugal encontra-se em uma situação intermediária, apresentando mais aspectos consociativos que majoritários; a Espanha é mais majoritária que consociativa; a Grécia situa-se entre as democracias mais majoritárias do mundo ocidental. Vê-se que a relação é bastante variável, com organizações políticoinstitucionais que tanto podem favorecer a tomada de decisões por uma maioria executiva, quanto fortalecer as minorias políticas presentes no Legislativo.

Essa parece ser uma questão importante no caso brasileiro, cabendo verificar em que medida o crescente grau de interferência do poder Executivo no Congresso é um indício de que o país caminha para um modelo majoritário de democracia (aliás, em conformidade com a tendência dos sistemas presidencialistas de governo $\left.{ }^{18}\right)$. Em realidade, os critérios de medida adotados por Lijphart são de difícil averiguação no Brasil, observando-se grande controvérsia teórica quanto a esse ponto. Contudo, parece que o "índice de iniciativa legislativa" sugerido por Leonardo Morlino (1998) é um indicador mais operacionalizável para analisar o grau de controle do Executivo sobre os partidos presentes no Legislativo.

Visto sob esse ângulo, os resultados no Brasil são bastante significativos. Dados do PRODASEN demonstram que, durante o período entre 19951999, a produção legislativa de iniciativa do Executivo correspondeu a $81 \%$ da legislação sancionada. Como se observa no Quadro I, cerca da metade $(47 \%)$ corresponde à prerrogativa constitucional do poder Executivo de enviar ao Congresso projetos orçamentários e solicitar liberação especial no orçamento da União (solici-

18 Os primeiros artigos de Lijphart sobre as democracias majoritárias e consociativas são cautelosos na afirmação de que o sistema presidencialista é tendencialmente majoritário (LIJPHART, 1984). Essa idéia vai aparecer plenamente configurada no final dos anos 80. Ver o artigo de Arend Lijphart, Presidencialismo e democracia majoritária, em Lamounier (1991); ver também sobre a autonomia dos Presidentes americanos em Katz (1996). 
tações para liberação de verbas). As medidas provisórias corresponderam a $17 \%$ do total da legislação, sendo que, destas, somente 5\% foram transformadas em projetos de lei de conversão. Portanto, a maioria das medidas provisórias foi aprovada na íntegra, sem receber emendas do Legislativo $^{19}$. O Executivo conseguiu aprovar, ainda, projetos de leis ordinárias, leis complementares e emendas constitucionais.

\section{Quadro I}

Tipo e origem da legislação sancionada e promulgada (1995-1999)

\begin{tabular}{|c|c|c|}
\hline ORIGEM & N$^{\circ}$ ABS. & $\%$ \\
\hline Medidas Provisórias (Executivo) & 116 & 12 \\
\hline Leis de Conversão (Executivo) & 49 & 5 \\
\hline Projetos Orçamentários (Executivo) & 470 & 47 \\
\hline Projetos do Executivo* & 167 & 17 \\
\hline Projetos do Senado* $^{*}$ & 41 & 4 \\
\hline Projetos da Câmara* $^{*}$ & 150 & 15 \\
\hline TOTAL $^{20}$ & 993 & 100 \\
\hline
\end{tabular}

* Projeto de Lei Ordinária, Lei Complementar e Emenda Constitucional.

Fonte: SENADO FEDERAL. PRODASEN [Online].

Embora sejam dados contundentes, um quadro comparativo com as democracias do sul da Europa é útil para relativizar a questão, uma vez que esses países desenvolveram modelos que oferecem um mosaico de possibilidades. Segundo o Quadro II, no início da democratização a interferência do poder Executivo foi muito intensa em todos os países. Isso ocorreu mesmo na Itália, que possui um Parlamento sabidamente atuante e que se caracteriza por apresentar alto grau de consociativismo entre governistas e oposição. Contudo, à medida que transcorriam as legislaturas, a força do Parlamento italiano cresceu rapidamente, embora nunca tenha atingido a maioria percentual das aprovações. Somente durante a década de 90 - ou seja, 50 anos depois - vem ocorrer uma mudança drástica que inverte a relação: o percentual de aprovações dos projetos do Executivo caiu para 11! Isso é explicado pela crise política decorrente dos escândalos e denúncias de corrupção que abalaram toda a Itália.

Portugal também se insere entre os países de Parlamento forte, pois em nenhum momento o Executivo foi plenamente dominante. No início, a relação era de $64 \%$ de aprovações do Executivo para 35\% do Parlamento. Vinte anos depois, a situação inverteu-se.

Espanha e Grécia têm sido considerados os países mais fortemente majoritários. A Espanha vem mantendo um alto percentual de interferência do Executivo, embora durante as duas últimas legislaturas esse índice tenha decrescido significativamente. O caso da Grécia é mais impressionante, pois durante duas décadas foi nula a capacidade de o Legislativo aprovar leis de sua autoria. Como analisa Leonardo Morlino (1998), a legitimidade da democracia grega não foi abalada porque o sistema político daquele país permite que o Parlamento interfira decisivamente nos projetos em tramitação, garantindo aos partidos presentes no Legislativo, inclusive aos partidos da oposição, que apresentem emendas que são incorporadas ao projeto original. Segundo ele, somente essa possibilidade de interferência explicaria a permanência de um sistema tão fechado quanto o grego.

Quadro II

Tipo e origem da legislação sancionada e promulgada (1995-1999)

ITÁLIA

\begin{tabular}{|c|c|c|c|c|c|c|c|c|}
\hline & $\mathbf{1 9 4 8 - 5 3}$ & $\mathbf{1 9 5 3 - 5 8}$ & $\mathbf{1 9 5 8 - 6 3}$ & $\mathbf{1 9 6 3 - 6 8}$ & $\mathbf{1 9 6 8 - 7 2}$ & $\mathbf{1 9 7 2 - 7 6}$ & $\ldots$ & $\mathbf{1 9 9 4 - 9 6}$ \\
\hline Executivo & 88,8 & 74,7 & 73,2 & 69,3 & 70,3 & 75,8 & 11,3 \\
\hline Legislativo & 11,2 & 25,3 & 26,8 & 30,7 & 29,7 & 24,2 & 88,7 \\
\hline
\end{tabular}

GRÉCIA

\begin{tabular}{|c|c|c|c|c|c|c|c|c|}
\hline & $\mathbf{1 9 7 4 - 7 7}$ & $\mathbf{1 9 7 7 - 8 1}$ & $\mathbf{1 9 8 1 - 8 5}$ & $\mathbf{1 9 8 5 - 8 9}$ & $\mathbf{1 9 8 9}$ & $\mathbf{1 9 8 9 - 9 0}$ & $\mathbf{1 9 9 0 - 9 3}$ & $\mathbf{1 9 9 3 - 9 5}$ \\
\hline Executivo & 99,9 & 100 & 100 & 100 & 100 & 100 & 99,7 & 100 \\
\hline Legislativo & 0,1 & - & - & - & - & - & 0,3 & - \\
\hline
\end{tabular}

19 As medidas provisórias não apreciadas pelo Congresso Nacional não foram computadas nessa análise.

20 Não foram considerados os Decretos (do Legislativo e
Executivo), as Resoluções e as Leis de autoria da Justiça (Ministério Público, Supremo Tribunal Federal e Supremo Tribunal do Trabalho). 


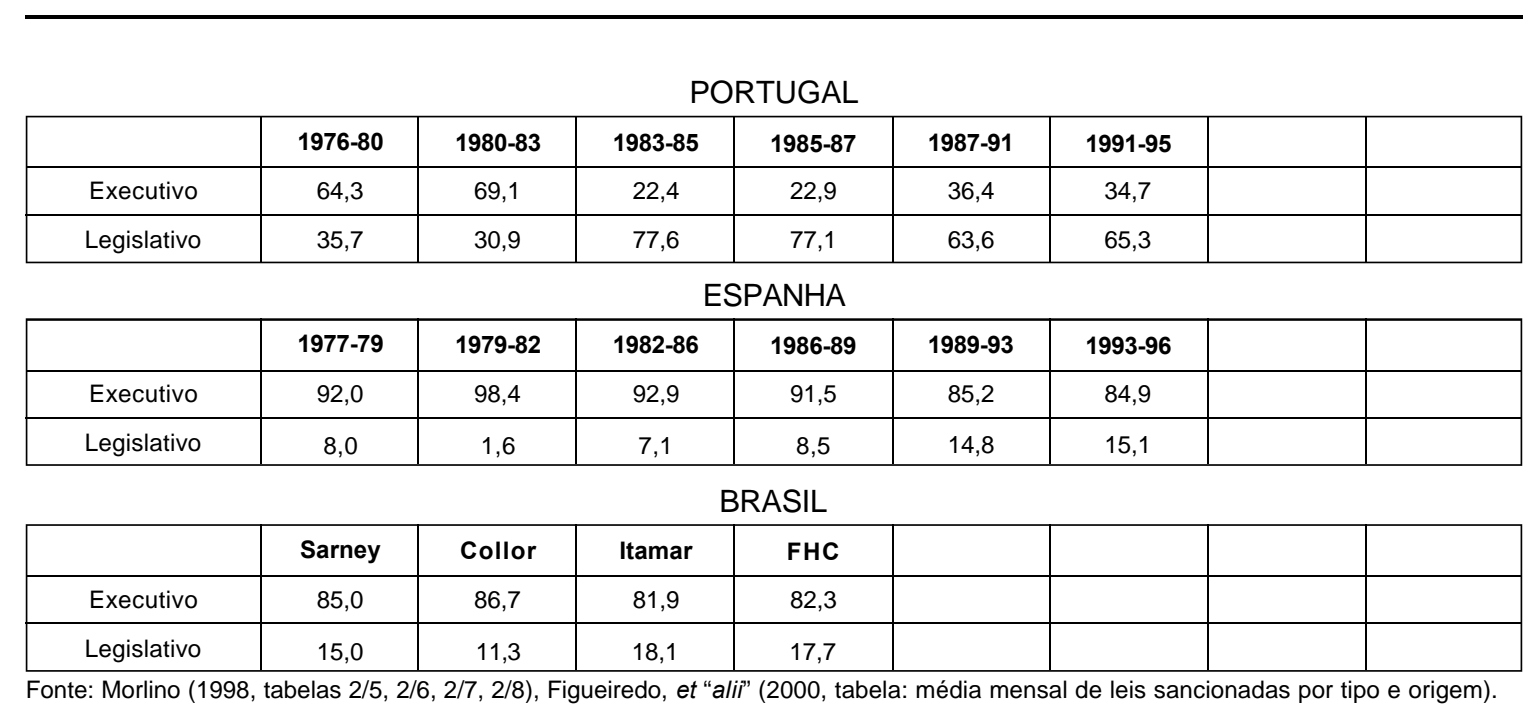

Comparando esses casos com o Brasil, alguns pontos merecem ser salientados. Em primeiro lugar, em contraste com as outras democracias, a democratização brasileira tem pouco mais de dez anos de funcionamento, e esse período parece insuficiente para definir o modelo democrático no qual o país se insere. Realmente, o percentual de interferência do Executivo tem sido bastante alto no Brasil (aproxima-se da situação espanhola das últimas décadas), mas é preciso considerar as peculiaridades desta fase da política brasileira.

Conforme tem argumentado Vicente Palermo, o Brasil enfrentou durante o período de transição uma situação de excepcionalidade que combinou dois problemas: a crise econômica e a necessidade de recomposição do Estado. A superação desses obstáculos, aliada a uma transformação nas expectativas sociais, "convergem criando condições favoráveis para uma nova etapa de reformas" (PALERMO, 2000b, p. 88). Como o Quadro II deixa claro, a relação entre os poderes é bastante dinâmica e pode sofrer mudanças drásticas com o transcorrer das legislaturas. $\mathrm{O}$ que se percebe é que o comportamento eleitoral da população exerce, significativamente, influência nesse processo e o poder Legislativo encontra-se diretamente relacionado a esta dinâmica eleitoral ${ }^{21}$. Visto sob esse ângulo, crescem os indícios de que a presença do Legislativo tende a aumentar nos próximos anos.

\footnotetext{
21 Estudos recentes vêm demonstrando que no caso brasileiro o alto número de partidos parlamentares relevantes deve-se à diversidade de opiniões presentes na sociedade brasileira atual; cf. Nicolau (1996) e Oliveira (1997).
}

\section{IV.2 DA TRANSIÇÃO À CONSOLIDAÇÃO}

Um segundo ponto a se refletir é o processo de consolidação propriamente dito. Nos países europeus considerados, há grandes diferenças nos processos de transição no que diz respeito ao tratamento dispensado aos segmentos que participaram ou apoiaram a ditadura. Como foi dito anteriormente, o caso espanhol é um exemplo de transição pactuada visto que, desde o primeiro momento, todas as forças políticas, inclusive os detentores do poder autoritário, compreenderam a necessidade de romper com o passado e inaugurar a democracia.

Diferentemente, em Portugal, na Grécia e na Itália a transição deu-se por meio de ruptura, uma vez que nos três países o governo ditatorial foi destituído do poder. Da mesma forma, os três apresentavam relevantes partidos anti-sistema, mas o desenvolvimento histórico a esse respeito variou bastante. Como é possível perceber, o dilema entre romper ou não com os segmentos que apoiaram o governo autoritário, muito mais que um ato de vontade, é o resultado de circunstâncias históricas que independem da ação dos indivíduos $^{22}$.

Parece lícito supor que, no caso do Brasil, bem como no dos outros países analisados, os problemas da transição não devem ser considerados obstáculos intransponíveis para o aprimoramento democrático. A permanência no poder dos segmentos sociais e políticos que apoiaram o regime

\footnotetext{
22 Sobre os limites e/ou potencialidades da democratização no Brasil, cf. Silva (1995).
} 
militar é uma característica que deve ser considerada, mas não deve ser compreendida como um fator determinante para o futuro da democratização.

Conforme se viu no item anterior, muito mais decisivas para o processo de consolidação foram as atitudes tomadas pelos grupos sociais que participam do jogo político. O mais importante para a consolidação parece ser o apoio aberto - da opinião pública, das organizações e dos partidos políticos - à democracia. Analisando-se os rumos da democratização européia, nota-se que a influência dos partidos políticos foi fundamental. E, apesar das flagrantes diferenças no caráter desses partidos, estudos demonstram que é possível extrair um sentido nesses processos históricos que deram certo.

Quanto à questão da polarização ideológica, por exemplo, somente devem ser considerados prejudiciais à democracia os partidos anti-sistêmicos que atuam contra as regras institucionais, negando a legitimidade democrática. Quando isso não acontece, e os partidos aceitam a disputa parlamentar (como foi o caso do partido comunista italiano e do socialista PASOK), a polarização pode ser um poderoso aliado do fortalecimento partidário entre a população. $\mathrm{O}$ mesmo acontece em relação às demandas fragmentadas da sociedade, que nem sempre são negativas.

Para Leonardo Morlino (1995; 1998), um dos elementos-chave dessa relação parece ser a capacidade encontrada pelos partidos em canalizar as reivindicações da sociedade, de modo a controlálas como uma espécie de gatekeeper. Independentemente da natureza das demandas, crescem as chances de consolidação democrática quando os partidos ou as lideranças partidárias exercem controle sobre a sociedade organizada, auxiliando o processo de centralização decisória. Leonardo Morlino apresenta várias possibilidades de relacionamento entre os partidos, a sociedade e o Estado e constrói uma tipologia, mostrando em cada caso as consequiências para a democratização.

$\mathrm{Na}$ consolidação via Estado, existe uma consensual legitimidade democrática e $\mathrm{o}$ atendimento às demandas sociais acontece predominantemente pela utilização de recursos do Estado, ou seja, através da patronagem, do clientelismo político e do corporativismo. No processo de consolidação via elites, o consenso democrático aparece da mesma forma, mas não se verifica uma ligação clara entre grupos organizados e partidos, os quais conseguem atuar com neutralidade em relação a essas demandas. Nesse caso, são as lideranças políticas e partidárias que tomam a frente do processo, ditando os rumos da democratização. Quando prevalece a consolidação via partidos, a sociedade encontra-se dividida por partidos antisistema que impedem o consenso democrático. Entretanto, se esses partidos mantiverem relevante envolvimento com a sociedade civil e se adaptarem às regras do jogo democrático, poderão atuar como intermediadores entre a sociedade e o Estado e, assim, beneficiar o processo de consolidação. A questão se agrava e as chances de democratização efetivamente diminuem quando coexistem dois problemas: de um lado, não prevalece um claro consenso democrático; de outro, os partidos são incapazes de controlar as demandas multifacetadas que partem da sociedade. Nesse caso, os interesses privados adquirem vida própria, encontrando canais abertos em direção ao Estado.

Com a finalidade de analisar essa questão, foi desenvolvida uma pesquisa sobre a legislação sancionada no Brasil entre 1995 e 1999 com origem na Câmara dos Deputados. O Quadro III procura estabelecer a relação entre o número dos Deputados por partido presentes na Câmara Federal e a quantidade de leis sancionadas ${ }^{23}$, verificando em que medida os partidos de sustentação do governo - que são absolutamente dominantes em números absolutos - sufocam, de fato, os partidos da oposição. Os dados são surpreendentes.

Conforme se vê, o índice de aprovação é de um modo geral baixo, mas nota-se que determinados partidos não têm como prioridade a aprovação de projetos de lei. Isso acontece com partidos grandes e governistas, como o PFL e o PPB que, apesar de sua enorme bancada, aprovaram apenas 16 projetos cada um. Diferentemente, o PMDB é um partido atuante, com um índice bem superior de aprovações. Outro dado da tabela é

\footnotetext{
23 Leis Ordinárias e Complementares com origem na Câmara Federal, sancionadas entre 1995 e 1999.
} 
que os micro-partidos apresentam uma taxa de aprovação bastante baixa, o que pode indicar uma certa dificuldade em colocar seus projetos na pauta legislativa.

Quadro III

Relação entre número de Deputados e aprovação de projetos com origem na Câmara

\begin{tabular}{|c|c|c|c|}
\hline Partidos & Deputados* & TNJR ${ }^{\star *}$ & $\begin{array}{l}\text { Taxa de aprovação } \\
\text { (por } 10 \text { deputados) }\end{array}$ \\
\hline PPB & 72 & 16 & 2,2 \\
\hline PFL & 110 & 16 & 1,5 \\
\hline PTB & 22 & 7 & 3,2 \\
\hline PMDB & 98 & 35 & 3,6 \\
\hline PSDB & 91 & 28 & 3,1 \\
\hline PT & 49 & 22 & 4,5 \\
\hline PDT & 21 & 6 & 2,9 \\
\hline Outros esquerda ${ }^{\star * *}$ & 30 & 7 & 2,3 \\
\hline Micropartidos ${ }^{\star * \star *}$ & 20 & 4 & 2,0 \\
\hline Comissões & - & 5 & - \\
\hline TOTAL & 513 & 146 & 2,8 \\
\hline
\end{tabular}

* Número de filiados em 1998, ou seja, ao final da 50ª legislatura.

** TNJR - Leis Ordinárias e Complementares Transformadas em Normas Jurídicas.

*** Outros de esquerda: PSB/PcdoB/PPS/PV/PSTU.

**** Micropartidos: PTN/PSC/PST/PL/PSL/PMN/PSD/sem partido.

FONTES: TSE, Eleições 1994 [Online]; SENADO FEDERAL. PRODASEN [Online]; CÂMARA FEDERAL, 2000.

Entretanto, o curioso é que os partidos de oposição apresentam índices altos de aprovação de projetos. O PT é - de longe - o partido com relação mais positiva entre número de deputados e leis sancionadas. O PDT apresenta desenvoltura mais modesta, mas também positiva. Esses são os partidos da oposição que apresentam uma bancada bastante reduzida: eram 49 deputados do PT e 21 do PDT em 1998, de um total de 513 deputados. Vê-se, portanto, que tais partidos não têm se limitado ao exercício crítico, mas sim que vêm assumindo com determinação uma postura de governo. É inegável a importância disso para a democracia.

Outra questão pertinente é a natureza da legislação proposta pelo Legislativo, pois são dados que, se conhecidos, podem esclarecer em que medida o Legislativo mantém-se como reduto dos interesses privados e das demandas fragmentadas da sociedade civil. Com o objetivo de fazer essa verificação, foi realizada uma análise desses projetos sancionados (com origem na Câmara Federal). Procurou-se observar se os projetos apresentam um caráter eminentemente privado, voltado para interesses particulares da sociedade, ou se prevalecem as questões de conteúdo político mais abrangente.

Adotou-se o seguinte critério em relação à análise:

1. Questões de Estado: envolvem dois aspectos: primeiro, a legislação especificamente relacionada ao Estado e ao funcionamento da burocracia estatal (as chamadas questões burocráticas); segundo, leis que dizem respeito às questões políticas mais amplas de organização da sociedade e da vida pública (as chamadas políticas de governo).

2. Direitos civis, politicos e difusos: relativos às questões amplas da cidadania, as quais atingem a todos os cidadãos indistintamente, sem especificar um segmento social determinado.

3. Direitos sociais: consistem, além da clássica noção de que Educação e Saúde são prerrogativas do Estado para atender aos cidadãos, também as leis que procuram atingir e favorecer a determinados segmentos sociais (as 
chamadas minorias políticas), dando a eles um tratamento exclusivo.

4. Corporativismo e localismo: circunscrevem a legislação que atinge a grupos sociais específicos, claramente determinados. Não existe nessa classificação nenhum julgamento de valor, pressupondo-se que os interesses restritos são, tanto quanto os outros, plenamente legítimos em uma democracia.

5. Outros: engloba a legislação que não se encaixa nos itens anteriores. Reduz-se a dois casos específicos: as homenagens e a legislação sobre os feriados.

Partindo desses critérios, a análise da legislação ordinária e complementar com autoria na Câmara Federal levou aos resultados apresentados na Ta- bela I. Em termos gerais, observa-se que a maioria dos projetos aprovados diz respeito às questões de Estado (40\%). Em segundo lugar, são contemplados os direitos sociais (22\%); defesa de interesses corporativos ou legislação que venha a atender regiões específicas somam $16 \%$ do total; direitos civis, políticos e difusos ocupam $13 \%$ da legislação.

Pelos números não é possível verificar o grau de interferência de um partido sobre o projeto do outro, mas sabe-se que essa interferência ocorre e que a legislação aprovada pode muitas vezes ser substancialmente diversa do projeto originalmente apresentado. Evidentemente, isso acontece também com os projetos apresentados pelo Executivo, o que atenua em grande parte a predominância avassaladora dessa esfera de poder.

\section{Tabela I}

Natureza da legislação sancionada (1995-1999), segundo autoria partidária na Câmara dos Deputados (em porcentagem)

\begin{tabular}{|c|c|c|c|c|c|c|c|c|c|}
\hline & PFL & PPB & PSDB & PMDB & PT & $\begin{array}{l}\text { Pequenos } \\
\text { esquerda }\end{array}$ & Micropartidos $^{* *}$ & Comissões & TOTAL \\
\hline Questões de Estado & 25 & 25 & 43 & 29 & 41 & 46 & 64 & 100 & 39 \\
\hline Direitos civis, políticos e difusos & 6 & 6 & 32 & 11 & 18 & 8 & 0 & 0 & 14 \\
\hline Direitos Sociais & 19 & 19 & 3,5 & 40 & 36 & 23 & 9 & 0 & 23 \\
\hline Corporativismo e localismo & 31 & 31 & 18 & 17 & 0 & 8 & 18 & 0 & 16 \\
\hline Outros & 19 & 19 & 3,5 & 3 & 5 & 15 & 9 & 0 & 8 \\
\hline № ABSOLUTO & 16 & 16 & 28 & 35 & 22 & 13 & 11 & 5 & 146 \\
\hline
\end{tabular}

Pequenos de Esquerda: PDT/PSB/PcdoB/PPS/PV/PSTU

Micro Partidos: PTB/PTN/PSC/PST/PL/PSL/PMN/PSD/sem partido

FONTE: SENADO FEDERAL. PRODASEN [Online]. SENADO FEDERAL Sistema de Informações do Congresso Nacional [Online].

A tabela mostra que os partidos apresentam feições claramente diferenciadas. Partidos como o PFL e PPB apresentam uma preocupação mais nítida com questões particulares, como interesses corporativos e representação dos interesses locais (31\%). Encontra-se também entre esses partidos o maior número absoluto e percentual de "outros", ou seja, há entre esses dois partidos uma preocupação específica com as homenagens.

No que diz respeito às questões relativas aos direitos civis, políticos e difusos, o PSDB aparece em primeiro lugar. E os direitos sociais são defendidos primeiramente pelo PMDB e, em segundo, pelo PT. Os pequenos partidos (sejam ou não de oposição) apresentam um número inferior de projetos aprovados, mas também entre eles prevalecem as temáticas relativas às questões de Estado (em primeiro lugar) e aos direitos sociais (em segundo lugar).
De fato, como a Tabela II simplificadamente demonstra, as divisões ideológico-partidárias evidenciam-se nessas questões. De um lado, as políticas mais abrangentes e de longo alcance têm sido uma preocupação predominante, inclusive entre os partidos de esquerda, que hoje formam a oposição ao governo. Em todos os casos analisados, questões de Estado e de cidadania ocupam mais de $50 \%$ da legislação originada nos partidos. De outro, a diferença entre esses percentuais é muito variada, com diferenças claras inclusive entre os partidos da coalizão de centro-direita, de apoio ao Presidente Fernando Henrique Cardoso. Observase, portanto, uma heterogeneidade na natureza da legislação proposta. Como é visível, $88 \%$ dos projetos aprovados com origem na esquerda $(43 \%+14 \%+31 \%)$ são de natureza social ampla. Esse percentual cai para $80 \%(35 \%+21 \%+24 \%)$ no centro ideológico e reduz-se para $54 \%$ $(31 \%+5 \%+18 \%)$ entre os partidos da direita. 
Tabela II

Natureza da legislação (1995-1999), segundo posição ideológica dos partidos de origem

\begin{tabular}{|c|c|c|c|}
\hline Natureza da legislação & $\begin{array}{c}\text { Esquerda } \\
\text { (PT/PDT/PPS/PSB/PcdoB) }\end{array}$ & $\begin{array}{c}\text { Centro } \\
\text { (PSDB/PMDB) }\end{array}$ & $\begin{array}{c}\text { Direita } \\
\text { (PFL/PPB/PTB) }\end{array}$ \\
\hline Questões de Estado & $15-43 \%$ & $22-35 \%$ & $12-31 \%$ \\
\hline Direitos civis & $5-14 \%$ & $13-21 \%$ & $2-5 \%$ \\
\hline Direitos sociais & $11-31 \%$ & $15-24 \%$ & $7-18 \%$ \\
\hline Corporativa e Localista & $1-3 \%$ & $11-17 \%$ & $12-31 \%$ \\
\hline Outros & $3-9 \%$ & $2-3 \%$ & $6-15 \%$ \\
\hline TOTAL & $35-100 \%$ & $63-100 \%$ & $39-100 \%$ \\
\hline
\end{tabular}

FONTE: SENADO FEDERAL. PRODASEN [Online]; SENADO FEDERAL Sistema de Informações do Congresso Nacional [Online].

\section{CONCLUSÃO}

Deve-se salientar que a produção legislativa de origem na Câmara Federal demonstra que todos os partidos, inclusive os partidos da oposição, têm participado co-responsavelmente da elaboração de políticas voltadas para a esfera pública. Os interesses particulares não apresentam trânsito livre pelo menos no que diz respeito à produção legislativa. Talvez essa seja uma indicação de que o caso brasileiro tende mais para o modelo de "consolidação via elites", proposto por Leonardo Morlino e analisado nas páginas deste artigo.
Mesmo admitindo-se a ampla dominância do poder Executivo durante o período analisado, observa-se que o poder Legislativo apresentou uma atuação relevante para o equilíbrio da democracia. A idéia do controle absoluto do Executivo sobre o Legislativo deve ser considerada com cuidado. Como é possível observar, o reduzido campo de atuação que cabe ao Legislativo tem sido produtivamente aproveitado, percebendo-se que a Câmara Federal é o espaço de atuação das oposições, que participam ativamente do processo legislativo.

Recebido para publicação em 19 de setembro de 2000.

Luzia Helena Herrmann de Oliveira (hermann@onda.com.br) é Doutora em Ciências Sociais na PUCSP e Professora de Ciência Política na Universidade Estadual de Londrina.

\section{REFERÊNCIAS BIBLIOGRÁFICAS}

ALIVIZATOS, N. 1990. The Difficulties of 'Rationalization' in a Polarized Political System : the Greek Chamber of Deputies. In : LIEBERT, U. \& COTTA, M. (eds.) Parliaments and Democratic Consolidation in Southern Europe : Greece, Italy, Portugal, Spain and Turkey. London/New York : Pinter.

CÂMARA DOS DEPUTADOS. 2000. Deputados Federais (1995-1999). 50ª Legislatura. Brasília : Câmara dos Deputados, Centro de Documentação e Informação (Bandep).

COTTA, M. 1990. The 'Centrality' of Parliament in a Protracted Democratic Consolidation : the Italian case. I $n$ : LIEBERT, U. \& COTTA, M. (eds.). Parliaments and Democratic Consolidation in Southern Europe : Greece,
Italy, Portugal, Spain and Turkey. London/New York : Pinter.

. 1996. La crise del governo di Partito all'Italia. In : COTTA, M \& ISERNIA, P. (org.). Il gigante dai piedi di argilla. Bologna : Il Mulino.

DAHL, R. 1997. Poliarquia. São Paulo : Edusp.

DI PALMA, G. 1990. Parliaments, Consolidation, Institutionalization : a Minimalist View. In : LIEBERT, U. \& COTTA, M. (eds.). Parliaments and democratic consolidation in Southern Europe: Greece, Italy, Portugal, Spain and Turkey. London/New York : Pinter.

DINIZ, E. 1997. Em busca de um novo paradigma. In : Crise, reforma do Estado e 
governabilidade (Brasil : 1985-95). Rio de Janeiro : Fundação Getúlio Vargas.

FIGUEIREDO, A. \& LIMONGI, F. 1996. Congresso Nacional : organização, processo legislativo e produção legal. Cadernos de pesquisa n. 5. São Paulo : CEBRAP.

1997. O Congresso e as medidas provisórias : abdicação ou delegação? Novos Estudos CEBRAP, São Paulo, n. 47, p. 127154, mar.

1998. Reforma da Previdência e instituições políticas. Novos Estudos CEBRAP, São Paulo, n. 51, p. 127-155, jul.

FIGUEIREDO, A., LIMONGI, F. \& VALENTE, A. L. 2000. Governabilidade e concentração do poder institucional : o governo FHC. Tempo social, São Paulo, v. 11, n. 2, p. 49-62, fev.

GUNTHER, R., DIAMANDOUROS, P. N. \& PUHLE, H.-J. (eds.). 1995. The Politics of Democratic Consolidation. Southern Europe in comparative perspective. Baltimore and London : John Hopkins University Press.

HAGOPIAN, F. 1992. The Compromised Consolidation : the Political Class in the Brazilian Transition. In : MAINWARING, S., O'DONNELL, G. \& VALENZUELA, S. (eds.). Issues on Democratic Consolidation : the New South American Democracies in Comparative Perspective. Notre Dame : University of Notre Dame Press.

HUNTINGTON, S. 1975. Ordem politica em sociedades em mudança. São Paulo : ForenseUniversitária/Edusp.

1991. The Third Wave. Democratization in the Late Twentieth Century. Oklahoma City. University of Oklahoma Press.

KATZ, R. S. 1996. The United States. In : BLONDEL, J. \& COTTA, M. (eds.) Party and Government : an Inquiry into the Relationship between Government and Supporting Parties in Liberal Democracies. London : Macmillan.

LAMOUNIER, B. (org.). 1991. A opção parlamentarista. São Paulo : Sumaré.

1995. Inequality against Democracy. In : DIAMOND, L., LINZ, J. \& LIPSET, S. M. (eds.). Politics in Developing Countries (Comparing Experiences with Democracy). $2^{\mathrm{a}}$ ed. London/Boulder : Linne Rienner.

1996. A democracia brasileira no limiar do século 21. São Paulo : Fundação KonradAdenauer-Stiftung. Série Pesquisas, n. 5.

LIJPHART, A. 1984. Democracies : Patterns of Majoritarian and Consensus Government in Twenty-One Countries. New Haven and London : Yale University Press.

LIJPHART, A., BRUNEAU, T. C., DIAMANDOUROS, N. \& GUNTHER, R. 1988. A Mediterranean Model of Democracy? The Southern European Democracies in Comparative Perspective. West European Politics, v. 11, n. 1, p. 7-25, Jan.

LINZ, J. \& STEPAN, A. 1999. A transição e consolidação da democracia. A experiência do sul da Europa e da América do Sul. São Paulo : Paz e Terra.

LINZ, J., STEPAN, A. \& GUNTHER, R. 1995. Transition and Consolidation in Southern Europe, with Reflections on Latin American. In : GUNTHER, R., DIAMANDOUROS, P. H. \& PUHLE, H.-J. (eds.). The Politics of Democratic Consolidation. Southern Europe in Comparative Perspective. Baltimore and London : John Hopkins University Press.

MAINWARING, S. 1993. Democracia presidencialista multipartidária : o caso do Brasil. Lua Nova, São Paulo, n. 23/24, p. 21-74.

MENEGUELLO, R. 1998. Partidos e governos no Brasil contemporâneo (1985-1997). São Paulo : Paz e Terra.

MORISI, M. 1991. Il Parlamento tra partiti e interessi. In : MORLINO, L. (org.). Costruire la democrazia : gruppi e partiti in Italia. Bologna : Il Mulino.

MORLINO, L. 1995. Political Parties and Democratic Consolidation. In : GUNTHER, R., DIAMANDOUROS, P. H. \& PUHLE, H.-J. (eds.). The Politics of Democratic Consolidation. Southern Europe in Comparative Perspective. Baltimore and London : John Hopkins University Press.

MORLINO, L. \& MONTERO, J. R. 1995. Legitimacy and Democracy in Southern Europe. In : GUNTHER, R., DIAMANDOUROS, P. H. \& PUHLE, H.-J. (eds.). The Politics of Democratic Consolidation. 
Southern Europe in Comparative Perspective. Baltimore and London : John Hopkins University Press.

1998. Democracy between Consolidation and Crisis. Parties, Groups and Citizens in Southern Europe. Oxford : University Oxford Press.

NICOLAU, J. 1996. Multipartidarismo e democracia. Rio de Janeiro : Fundação Getúlio Vargas.

1991. Sistemas eleitorais : exame da proporcionalidade da representação política e seus determinantes. Rio de Janeiro. Dissertação (Mestrado em Ciência Política). Instituto Universitário de Pesquisas do Rio de Janeiro.

O'DONNELL, G. 1996. Delegative Democracy. In : DIAMOND, L. \& PLATTNER, M. F. (eds.). The Global Resurgence of Democracy. $2^{\mathrm{a}}$ ed. Notre Dame : University of Notre Dame.

. 1999. Counterpoints. Selected Essays on Authoritarianism and Democratization. Notre Dame.

O'DONNELL, G. \& SCHMITTER, P. C. 1986. Transitions from Authoritarian Rule. Tentative Conclusions about Uncertain Democracies. Baltimore and London : Johns Hopkins University Press.

OLIVEIRA, L. H. H. 1997. Reformas institucionais e interesses políticos. Uma análise regional. Londrina : UEL.

PALERMO, V. 2000a. Como se governa o Brasil? $\mathrm{O}$ debate sobre instituições políticas e gestão de governo. Dados, Rio de Janeiro, v. 43, n. 3, p. 521-557.

2000b. Mares agitados : interpretações sobre os processos políticos latino-americanos : Brasil e Argentina em perspectiva comparada. Revista de Ciências Humanas, Florianópolis, CFCH-UFSC, p. 83-101, $1^{\circ}$ semestre.

PARAMIO, L. 1989. Agonia e morte de duas ditaduras : Espanha e Brasil. In : MOISÉS, J. A. \& ALBUQUERQUE, J. A. G. (orgs.). Dilemas da consolidação democrática. São Paulo : Paz e Terra.

PESSANHA, C. 1999. Medida (usurpação) por Medida (Provisória). Insight/Inteligência, n. 5, www.informe.com.br/inteligencia6/reformas.

SENADO FEDERAL. 2000a. Pesquisa da legislação brasileira (1995-1999). Senado Federal, Prodasen, Subsecretaria de Informações. www.senado.gov.br.

2000b. Sistema de informação do Congresso Nacional. www.senado.gov.br/sicon.

SHARE, D. \& MAINWARING, S. 1986. Transição pela transação : democratização no Brasil e na Espanha. Dados, Rio de Janeiro, v. 29, n. 2, p. 207-236.

SILVA, R. 1995. Democracia delegativa ou vicissitudes da transição? Revista de Sociologia e Política, Curitiba, n. 4/5, p. 175-188.

SOUZA, M. C. C. 1988. A Nova República brasileira : sob a espada de Dâmocles. In : STEPAN, A. (org.) Democratizando o Brasil. São Paulo : Paz e Terra.

TSE (Tribunal Superior Eleitoral). 1994. Eleições 1994. Deputado Federal $-1^{\circ}$ turno. www.tse.gov.br/eleições/eleições94.

WEFFORT, F. C. 1992. Novas democracias. Quais democracias?. In : WEFFORT, F. C. Qual democracia?. São Paulo : Companhia das Letras. 